\title{
Dynamics of Application of Halal Certification on Medicine Products in Indonesia
}

\author{
Asmuni $^{1}$, M. Jamil ${ }^{2}$, Fitri Rafianti ${ }^{3}$ \\ ${ }^{1,2,3}$ Universitas Islam Negeri Sumatera Utara, Indonesia
}

\begin{abstract}
Products are "goods and / or services related to food, beverages, drugs, cosmetics, chemical products, biological products, genetically engineered products, as well as used goods that are used, used or utilized by the public", while the halal certificate is a certificate issued by the Central or Provincial MUI regarding the case of a food product, foodstuff, beverage and medicine and cosmetics produced by the company after being examined and declared halal by an institution authorized to issue a halal product certification. In Article 4 of Law No. 33 of 2014 concerning the guarantee of halal products it states that "Products that enter, circulate and are traded in the territory of Indonesia must be certified halal". Normatively, the article clearly stipulates that drugs that enter, circulate and are traded in the territory of Indonesia must be guaranteed halal. However, the halal certification process for medicines in Indonesia is waiting for a long time due to various dynamics, this is the content of researchers seeing the gap between Law Number 33 of 2014 and the current reality, we should be able to reflect on other countries as well. Which is more advanced than Indonesia regarding halal certification.
\end{abstract}

\section{Keywords}

dynamics, halal certification; medicinal products

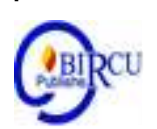

\section{Introduction}

A person's behavior will be greatly influenced by the type of food he consumes. In addition, prayers will not be answered if the food is forbidden. (Narrated by Muslim). Therefore, it is best for everyone not to consume something that he is not sure of its halal. In this context, the halal label is actually necessary. The halal label can help these people from doubting the status of the halal food they will consume.

The awareness of halal products is important for a Muslim. A Muslim who has awareness about their halal products not only think about labels or health only, but they will be loyal to halal products because they understand about the prohibition and what they get when consuming products that are not kosher. Spiritual values and religiality will influence behavior and action and become the basis of behavior directly and ultimately impact the choice of food they consume (Mahendra, 2020).

Wilson and Liu argue that halal is a central concept for sharia and Muslim beliefs, which includes a broader philosophy than just a product brand or marketing; it is ethos and moral code of ethics with a strong ethical attitude. While Toyyiban is another central concept of Sharia, with broader meanings related to virtue, linking goodness, cleanliness, health, and security (Noordin in Hasibuan, 2020).

In this case, the role of the state is very necessary to create a welfare state and protection, including for Muslim consumers, so in fact these goals are the state's interests / almașlahah al-dauliyyah. The role of the state in protecting Muslim consumers for halal products is control of misleading information. This role is obligatory kafa'i (collective 
responsibility) of massive and credential products with mandatory halal certification and labeling, because Muslim consumers cannot validate their halalness.

Islam highly values science as reflected in the first revelation that was revealed to the Prophet Muhammd SAW. Science can be obtained through several methods or one form of knowledge is through the scientific method with certain characteristics and produces science (Science / Scientific Knoeledge) for that researchers through several surveys conducted try to dig deeper into the obscure substance regarding the application of Law Number 33 of 2013 on food products, especially medicine, through various studies that can boost this problem.

Academic studies in the field of halal medicine as a consequence of the birth of Law no. 33 of 2014 has not been found by many people. The Ministry of Religion, for example, said that in 2008-2009, the World Halal Forum conducted a survey of the awareness of Indonesian Muslims regarding the halalness of a product. The survey results show that halal awareness of meat and processed products is $94-98$ percent, processed food is $40-64$ percent, medicine is 24-30 percent, and cosmetics and personal care products are 18-22 percent. Based on these conditions, the Research and Development Center (Puslitbang) of Religious Life then conducted a survey related to the Behavior of Urban Muslim Communities in Consuming Halal Products in 2013. The survey was conducted in 7 provinces in Indonesia, namely: DKI Jakarta, West Java, Riau Islands, Central Java, Bali, East Java and North Sulawesi. The selection of these seven provinces is based on dominant factors of culture and industrial dominance.

The survey results stated that the behavior of respondents related to the awareness of consuming halal products is at a high level with a behavior index value of 3.84 (on a scale of 5). It was explained that 73 percent of respondents checked the halal label before making a purchase decision for a product. This condition is supported by the State of the Global Islamic Economy (GIE) Report 2018/19 which states that Indonesians have spent US \$ 218.8 billion in 2017 to consume halal products. This means that there has been an increase in the consumption of halal products by 19.2 percent when compared to the previous year.

Medicines circulating in Indonesia can be classified into various variants. Generally, this classification consists of OTC Medicines; Potent drug; Pharmacist Mandatory Drugs; as well as Psychotropic and Narcotics Drugs. OTC drugs are drugs that can be used without a doctor's prescription, also known as OTC (over the counter) drugs. These over-the-counter drugs are generally easy to find not only in pharmacies, but also in stalls in general. Considering that this research seeks to understand the JPH Law in relation to halal medicines, it is also important to see how Islamic teachings lay the basic concept of these medicines. After all, Islam pays serious attention to the world of health because its teachings are universal in almost all aspects of human life. Mahran and Mubasyir state, none of the new things that are done by humans, as well as human science, unless there must be a proof in the Al-Quran, as stated in the verse:

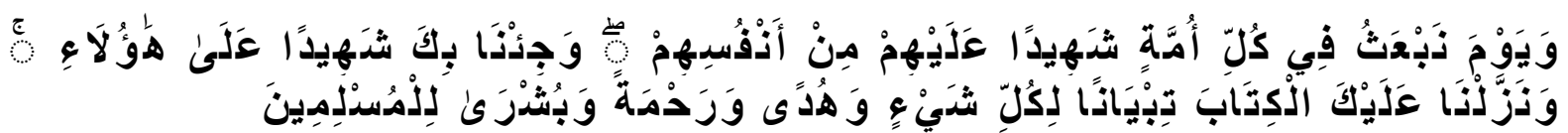

Meaning: "(And remember) the day (when) We raised up in each people a witness against them of their own and We bring you (Muhammad) to be a witness over all mankind. And we sent down to you the Al Kitab (Al Quran) to explain everything and guidance as well as grace and good news for those who surrendered. " (Surah An Nahl / 16: 89). 
There are two terms that are often equated with the term medicine in Arabic, namely: Syifa 'and Dawa.' The word syifa 'is a masdar of the word syafa-yusyafi-syifaun, which means healing, things that heal, and healing. Ibn Manzur defines it as a medicine that can cure disease, from which it can be understood that the word syifa "also gets the equivalent of the word dawa" in Arabic. Meanwhile, Ibn Faris emphasized that the terminology syifa 'was used because he had defeated the disease and healed it; which is in line with the terms al ra 'min al-marad (recovering from disease), syifa' al-salamah (safety medicine), which in a later stage of development this term is used as "healing."

The word syifa which refers to the definition of "healing" in the Qur'an is mentioned eight times, including Surat An Nahl verse 69; Surat Yunus verse 57; and Surat Fusilat verse 44. Meanwhile, the word dawa which refers to medicine is only found in a few traditions. From the above description, some commentators make a distinction between syifa 'and dawa' as follows: that syifa 'is used for both physical and physical conditions as well as spiritual; used in sick or healthy conditions; while dawa 'is used for one of the physical or spiritual conditions only when sick.

The Al-Quraan does not technically explain drugs as referred to in the medical world, but Muslim commentators and scientists rely on explanations of medicine to the Qur'an and hadiths.

Jurisprudence experts from various schools; namely the Hanafi, Maliki, Syafi'I scholars and the hambali mazhab scholars agree on whether someone is allowed to treat their illness. Prof. Dr. Nawir Yuslem revealed that the mazhab is the leading stream in Islamic law brought by certain imams (Syafi'i, Hambali, Maliki and Hanafi). The school of thought comes from the word zahaba which means to go, whereas according to the term it is the way of thinking, understanding and opinions taken by a mujtahid in establishing an Islamic law from the Qur'an and Hadith. Some scholars define mazhab as the opinion, understanding or flow of a great alim in Islam who is given the title as an Imam such as Imam Shafi'i, Imam Hambali, Imam Maliki and Imam Hanafi.

The opinions of these scholars are based on the many arguments that show the ability to treat diseases. As contained in the Book of Mughni al-Muhtaj by al-Syarbaini as follows:

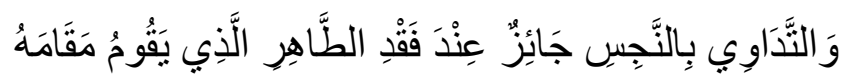

Meaning: "Treatment with unclean objects is permissible when there is no holy object that can replace it" Likewise, emphasized by Imam Izz Abd al-Salam in the book "Qawa'id al Ahkam fi Mashalih al-Anam" which means as follows: "May be treated with objects - unclean objects if they have not found a sacred object that can replace them, because the benefits of health and safety are more perfect (preferable) than the benefit of staying away from unclean objects".

The conclusion that can be drawn is that in health problems, the Qur'an seems to encourage preventive measures rather than treatment and healing (curative). Hamad Hasan Raqith gave a general explanation of health in Islam which holds the principle of maintaining health in a preventive manner, furthermore Islam recommends treatment for needy due to illness. According to him, this principle is in accordance with the characteristics, abilities and state of human nature. Likewise with the views of Imam Ibn Qayyim al Jauziyyah, who emphasized preventive efforts as a principle that must take precedence over treatment. Based on some of the research data above, the authors are interested in conducting research on the dynamics of halal certification. 


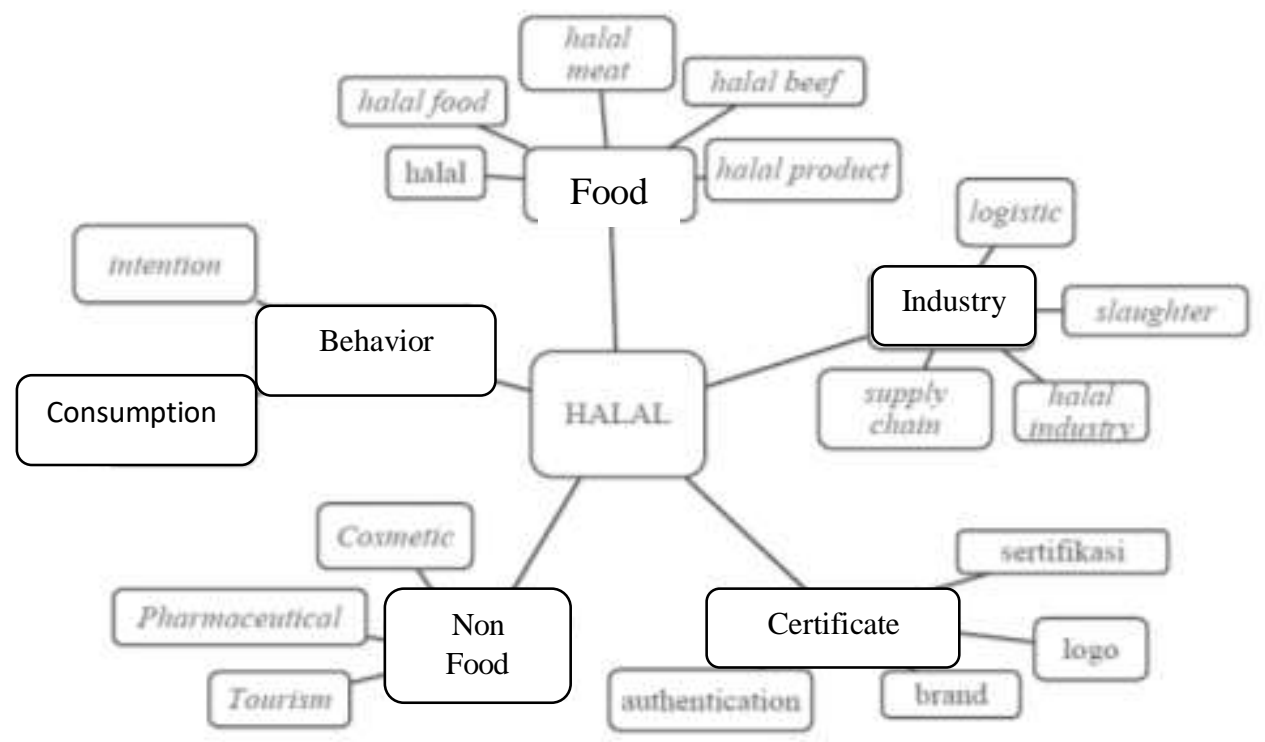

Figure 1. Halal in the pharmaceutical world

Although research on halal in the pharmaceutical world is starting to get attention, its existence is not yet maximized as can be understood based on the above figure. This condition is what motivates the authors to conduct this research with the title "Dynamics of Application of Halal Certification in Medicinal Products (Comparative Study of Islamic Law and Positive Law)".

\section{Review of Literature}

\subsection{Definition of Dynamics}

Dynamics is the continuous movement of society which is a change in the life order of the community concerned, so dynamics means change. Dynamics or changes in the field of law take the form of legal changes as a closed system and / or an open system.

Legal change as a closed system of internal legal dynamics follows Kelsen's opinion, namely legal changes that take place based on the hierarchical level of the law. In addition, there are changes taking place in society; for example, concerning the obedience of society to the law. This last change is in the form of changes in values, attitudes and behavior of the community towards the law. The latter is meant by the existence of the external dynamics of the law. Law is a social network that regulates all angles of culture with no real limits. The actual law cannot be sharply distinguished from the form of social behavior.5 law is also the work of humans in the form of norms containing behavioral guidelines which are a reflection of human will about how society should be fostered and where it should be directed. (Hartanto, 2020).

The definition of Halal Certification is an acknowledgment of the halalness of a product issued by BPJPH based on a written fatwa issued by the Indonesian Ulema Council. In addition, the halal fatwa produced by MUI is adhered to and obeyed by the government and Muslims. The meaning of medicine is all ingredients, either single or mixed, that are used by all creatures inside and outside, in order to prevent, alleviate, or cure disease. Meanwhile, according to statutory regulations, what is meant by drugs are substances intended to be used in determining the diagnosis, preventing, reducing, eliminating, curing disease or symptoms of illness, injury or physical or spiritual disorders in humans or animals, to beautify the body or parts of the human body. 


\section{Discussion}

\subsection{Dynamics of Application of Halal Certification in Medicinal Products in Positive Law}

As a predominantly Muslim country, halal certification can certainly be a necessity to ensure the safety of Muslims in consuming food or medicine. The government has launched halal certification since 2014 with the Halal Product Guarantee Act (JPH Law). Law Number 33 of 2014 concerning Halal Product Guarantee mandates that products in circulation must be certified halal. In this context, certification is specifically for the study of drugs.

Halal certification for pharmaceutical products is faced with several inhibiting factors such as a lack of raw material suppliers that meet halal requirements and constraints on halal management in the Indonesian Pharmaceutical Industry. However, obtaining and using halal medicine for every Muslim is a right guaranteed by the constitution. This paper seeks to provide an overview of the implementation of the Halal Product Guarantee Law in the fulfillment of halal medicinal products circulating and being traded in Indonesia. The method used is to collect literature related to the implementation of Law no. 33 of 2014 in the development of halal medicine in Indonesia and makes a summary of these literatures. The results of the review show that there is a need for joint efforts between pharmacists and related parties to complete the study of the halal management system with a systematic and scientific approach to produce halal drugs in accordance with Islamic law.

However, the facts about the guarantee of halal products on drugs are still very concerning. In fact, for vaccine products, according to data in MUI (MUI Fatwa No. 06/2010) there are only three vaccines that have obtained halal certification, namely three vaccine products for meningitis vaccination. In fact, data from LPPOM MUI of 30 thousand types of drugs registered at BPPOM and circulating in the public, only 34 drugs are halal certified. The number is very small when compared to the fact that the majority of Indonesians, who use these drugs are Muslims.

Therefore, as a pharmacist it is wise to take responsibility and obligation to continue doing research, to realize halal and thayyib drugs, including vaccine drugs for immunization. The morality of permitting the use of drugs that are haram, implicitly obliges the Islamic ummah, especially researchers in the field of pharmacy to conduct research and find medicines that contain halal and holy ingredients, so that they meet the syar'i standards for use by the Islamic ummah.

Based on the Halal Product Guarantee Law, it is known that the obligation to be halal certified for all products circulating and traded in Indonesia will be implemented five years after the enactment of the JPH Law (2019). As a pharmacist's effort to help implement the law, it is necessary to design a halal production guide for the pharmaceutical industry that is compatible with CPOB (Good Drug Use Method), in order to facilitate the process of producing halal drugs in the pharmaceutical industry. Before being marketed, drugs produced by the pharmaceutical industry must be guaranteed safe, nutritious and of high quality.

This can be proven by evidence of research data conducted by the related pharmaceutical industry and reported regularly to BPOM as the food and drug regulatory agency of the Republic of Indonesia. However, this process does not necessarily guarantee the halalness of a product. A product is said to be halal if it can be proven to be free from the critical point of drug halalness. The development of drug-making process technology is now increasingly advanced and makes consumers unaware of the content of medicinal ingredients on the market, therefore it is necessary to pay attention to the critical points of halal medicine, such as: 
1. Ensuring the halalness of the active ingredients, excipient ingredients and auxiliary materials used

2. Ensure that production facilities are used specifically for halal products only

3. Ensure there is no chance of being mixed and contaminated with prohibited materials from additives, auxiliary materials or from the facilities used

4. Ensuring the halalness of the packaging materials used

5. Carry out a process of washing and cleaning equipment according to the Sharia law

6. Allowing the Halal Auditor to conduct a direct audit process and determine the halalness.

The critical point of product halalness can be a reference in producing halal products before submitting the product halal certification process to BPJPH. If the pharmaceutical industry says that as long as the haram substance is good medicine and its use can be tolerated, it is quoted from Dr. Yusuf Qordhowi in his book Halam Haram fil Islam, this cannot be corrected, because "as long as there is a substance that has the same properties as the haram substance, then the substance is still declared haram", maybe this is the principle that must be applied in enforcing the JPH Law in products. medicine12.

The pharmaceutical industry that wants to produce halal pharmaceutical preparations is required to prepare a halal management system to ensure the continuity of the halal production process consistently. The halal management system is an integrated management system that is prepared, implemented and maintained to regulate materials, production processes, products, human resources and procedures in maintaining the continuity of the halal production process in accordance with predetermined requirements 13.

Halal by Design (HbD) is a conceptual approach to producing halal drugs in accordance with Islamic Sharia. HbD has the basis that the halalness of the product can be built into the product (Built-in to product). This concept is inspired by the concept of Quality by Design $(\mathrm{QbD})$, which is a systematic and scientific approach to halal product development that begins with planning, material selection, halal production and guaranteeing halal products based on halal management1. Following up on these proposals, it is necessary to prepare a halal certification device for drugs 11 , such as:

1. Standards / requirements for halal drugs (Halal Management System) by authorized parties (BPJPH in collaboration with other interested parties).

2. Applying the concept of Halal by Design for the pharmaceutical industry

3. Train Halal Supervisors in the Pharmaceutical Industry

Halal supervisor is a person or halal management team appointed by the leader of the business actor (Pharmaceutical Industry) and reported to BPJPH. Halal supervisor on duty

1. Oversee the process of halal products (PPH) in companies (pharmaceutical industry)

2. Determine corrective and preventive actions

3. Coordinating the halal product process

4. Accompany the Halal Auditor during the inspection (visitation) in the framework of halal certification.

5. Providing Halal Active Ingredient and Excipient Index Book

3.2 Dynamics of Application of Halal Certification in Medicinal Products in Islamic Law

Halal from a religious perspective, seen from the point of view of feasibility and health standards. The concept of health in Islam does not only prioritize physical health but also psychological health. In terms of maintaining health, Islam also emphasizes the concept that it is better to prevent than to cure because it will close the opportunity for bad consequences or preventive action for the effects they cause. Thus, prevention of legal disease is obligatory to realize a greater goal, namely complete benefit and health. Early prevention of the 
possibility of disease attacks, one of which is done is consuming drugs both for prevention and for the healing process.

Halal from a religious perspective, seen from the point of view of feasibility and health standards. The concept of health in Islam does not only prioritize physical health but also psychological health. In terms of maintaining health, Islam also emphasizes the concept that it is better to prevent than to cure because it will close the opportunity for bad consequences or preventive action for the effects they cause. Thus, prevention of legal disease is obligatory to realize a greater goal, namely complete benefit and health. Early prevention of the possibility of disease attacks, one of which is done is consuming drugs both for prevention and for the healing process.

The law of consuming drugs and vaccines is the same as the law of consuming other food products, which must be halal. which is based on the hadith of the Prophet Muhammad SAW narrated by Abu Daud from Abu Darda which reads: "Allah has sent down disease and medicine and made medicine for every disease; then seek treatment and do not seek treatment with unclean objects. For drugs for diseases that can be deadly, they can be treated in this way for emergency reasons, but for other diseases that can actually be treated with drugs that are not halal and the process that is doubtful can still be overcome by the composition of ingredients and the process of drugs that are halal. unclean or what is forbidden for medicine when there is no holy object that can replace it, as stated in the Book of Mughni al-Muhtaj by al-Syarbaini as follows:

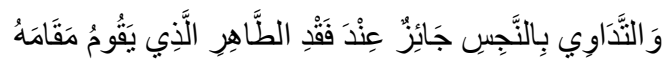

"Treatment with unclean objects is permissible when there is no holy object that can replace it".

Likewise, emphasized by Imam Izz Abd al-Salam in the book "Qawa'id al Ahkam fi Mashalih al-Anam" which means as follows: "May be treated with objects - unclean objects if they have not found a sacred object that can replace them, because the benefits of health and safety are more perfect (preferable) than the benefit of staying away from unclean objects"

Likewise, it can be seen from the affirmation of the Prophet Muhammad SAW

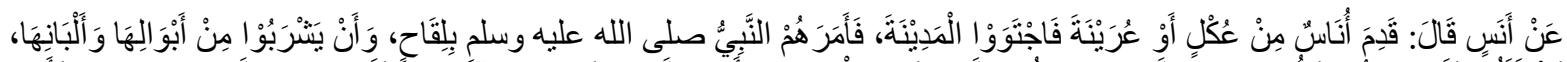

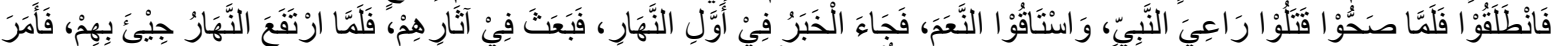

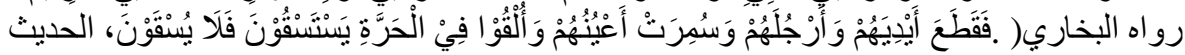

Meaning: A group of people from the tribe 'Ukl or' Urainah came and they were not compatible with the air of Medina (so they fell ill), so the Prophet ordered them to be given milk camels and drink the camel's urine and milk ... "(Narrated by AlBukhari).

In addition to the affirmation of the Prophet, there are several legal principles that explain

$$
\text { الضَّرُوْرَاتُ تُبِيْحُ أْلَحْظُوْرَاتِ }
$$

Meaning: "Emergency conditions allow things that are prohibited (forbidden)" 


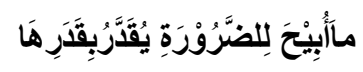

Meaning: "Something that is allowed because of an emergency is limited according to the level (of your needs)"

الضرر يزال

Meaning: "Dharar (danger) must be removed."

الحاجة قد تنزل منزلة الضرورة

Meaning: "The condition of hajah occupies an emergency."

In addition to the things above, Imam Syafi'i explained about medical treatment, according to the Syafi'i school of thought, as explained by an-Nawawi in al-Majmu 'treatment with an unclean object other than the law is permissible, provided that.

There is no medicine derived from a holy substance that can replace it, if there is a medicine made from a holy substance it is haram to treat it with an unclean object, and If indeed the unclean object is known - by medical science - has medicinal properties and there is no other medicine made from a sacred substance that can replace it.

This understanding is taken from the hadith narrated by al-Bukhari and Muslim about people from 'Urainah who were treated with camel urine, and camel urine according to the school of Shafi'i, the law was unclean. And they understand the hadith 'Verily Allah has not made your healing from anything that is haraam against you. the ability to seek treatment with unclean objects in an emergency, this is a valid opinion according to the jumhur 'ulama Syafi'iyah, as mentioned by an-Nawawi and ar-Rafi'i. They argue with the hadith narrated by Muslims, from Wail ibn Hujr radhiyallahu 'anhu, that Tariq ibn Suwaid al-Ju'fi asked the Prophet sallallaahu' alaihi wa sallam about khamr, and the Messenger of Allah forbade it and hated its manufacture, Tariq then said, 'I made it as medicine ', Rasulullah then replied' It is not a medicine, but a disease. To provide certainty for the Muslim community in Indonesia, the Indonesian Ulema Council specifically on 20 July 2013 issued a fatwa on Medicine and Medicine. The fatwa contains six dictums of legal provisions and four recommendations. The fatwa in full is as follows:

1. Islam requires treatment because it is part of protection and health care which is part of maintaining Al-Dharuriyat Al-Khams.

2. In seeking healing, it is mandatory to use medical methods that do not violate Shari'a.

3. Drugs used for medicinal purposes must use holy and lawful ingredients.

4. The use of unclean or haram substances in medicines is haram.

5. The use of drugs made from unclean or haram ingredients for treatment is haram unless they meet the following requirements:

a. is used in a condition of coercion (al-dlarurat), namely a condition of compulsion which if not done can threaten human life, or a condition of urgency which is equivalent to an emergency (al-hajat allatitanzilu manzilah al-dlarurat), namely a condition of urgency which if not carried out will can threaten the existence of the human soul in the future;

b. not found any material that is lawful and holy; and

c. There is a recommendation from a competent and trusted paramedic that there is no halal medicine.

6. The use of drugs made from unclean or haram substances for illegal treatment may be subject to purification. 
In the fatwa, it is generally described that there are two conditions, each of which gives birth to different laws. The first condition is general and normal conditions (fi halat alikhtiyar). The first four dictums in the fatwa above are to regulate in general and normal conditions. The second condition is a special and abnormal condition (fi halat al-idhtirar). The legal provisions in the fifth dictum provide this explanation. The use of drugs made from unclean or haram for treatment is basically haram. However, the prohibition is exempted in two conditions, firstly in a condition of compulsion (al-dlarurat), namely a condition of compulsion which if not carried out can threaten human life, and 'Rasulullah sallallahu' alaihi wa sallam prohibits treatment with dirty drugs (khabits) is If a medicine is obtained from a holy substance, and if there is no such medicine, then it is permitted to seek treatment with an unclean object other than wine. Al-Baihaqi, as quoted by an-Nawawi, asserts that the last two hadiths, if authentic, are prohibited from seeking treatment with something that is intoxicating and treatment with what is haram without any emergency conditions, as a form of jama 'between the two hadiths and the hadith. about the 'Urainah people. Second, a condition of urgency which is equivalent to an emergency (al-hajat allatitanzilu manzilah aldlarurat), which is a condition of urgency which, if not done, can threaten the existence of the human soul in the future. These two conditions are not sufficient to permit the consumption of drugs made from haram or unclean.

\section{Conclusion}

From the explanation that the author has explained above, it can be seen that the application of halal certification to medicinal products experiences a variety of dynamics and problems and obstacles of various things, unpreparedness in accepting the consequences that all products must be certified halal is a scourge for the pharmaceutical industry because

\section{References}

Abul Fadl Mohsin Ebrahim. (1993).Biomedical Issues: Islamic Perspective (Kuala Lumpur: A.S. Noordeen)

Abdul Hakim. (2020). "Obat dan Kesehatan dalam Perspektif Alquran," (Online), https:// inpasonline.com/obat-dan-kesehatan-dalam-perspektif-al-quran/, diakses 1 Mei.

Ahmad Warson Munawwir, Al Munawwir.(1997). Kamus Arab-Indonesia (Surabaya: Pustaka Progressif)

Alex Chandra, SH, SE, M.Hum. (2020).https://www.metrokaltara.com/dosen diakses pada 27 september,pukul 20.09 Wib

al-'Izz bin 'Abd al-Salam, Qawa'id al-Ahkam fi Mashalih al-Anam, Kairo: Mathba'ah alIstiqamah, t.th.), juz I, h. 81.

Aswadi.(2012). Konsep Syifa' dalam Al-Qur'an (Jakarta: Kementrian Agama Republik Indonesia)

Eno Soetopo, et al (Tim Penyusun). (2004).Ilmu Resep Teori. (Jakarta: Badan Pengembangan dan Pemberdayaan Sumber Daya Kesehatan Depatemen Kesehatan RI)

Faisar Ananda Arfa, M.A., Dr. Watni Marpaung, M.A. (2010). Metodologi Penelitian Hukum Islam, Bandung: Penerbit Citapustaka Media Perintis.

Hartanto, D. (2020). Sociology Review of Social Phenomenon, Social Rules and Social Technology. Budapest International Research and Critics Institute-Journal (BIRCIJournal). P. 1175-1184

Hasan, Sofyan. (2014). Kepastian Hukum Sertifikasi dan Labelisasi Halal Produk Pangan. Jurnal Dinamika Hukum. Vol 14. No 2 
Hasibuan, S. et al.(2020). The Effect of Health and Religious Beliefs on Consumer Consciousness of Using Halal Cosmetics. Budapest International Research and Critics Institute-Journal (BIRCI-Journal). P. 239-249

Ibnu Manzur, Lisan Al Arab, (Qahirah: Dar Ma"arif, 1119)

Jamaluddin Mahran dan Abrul Azhim Hafna Mubasyir. (2006). Al-Quran Bertutur tentang Mahanan dan Obat-Obatan (Yogyakarta: Mitra Pustaka)

Jurnal Baabu Al-Ilmi Vol.2 No.1 April 2017

Kosmetika Halal atau Haram serta Sertifikasinya. Majalah Farmasetika. Vol. 2

Mahendra,W. et al.(2020). The Influence of Religiusity and Halal Label through Halal Awareness Purchase Decisions. Budapest International Research and Critics InstituteJournal (BIRCI-Journal).P. 1739-1746

Mashudi. (2015). Konstruksi Hukum dan Respons Masyarakat Terhadap Sertifikasi Produk Halal, Cetakan ke-1 (Yogyakarta: Pustaka Pelajar)

M.Jamil. (2017). Fiqih Perkotaan, Medan : Perdana Publishing.

Muhammad al-Khathib al-Syarbaini, Mughni alMuhtaj, (Beirut: Dar al-Fikr, t.th.), juz I, h. 79).

Nawir Yuslem. (2013). Metodologi Dan Pendekatan Dalam Pengkajian Islam, Cet. I (Bandung: Citapustaka Media)

Rifda Latifa. (2020).Obat dan Penggolongannya (Online), https://www.academia.edu/ 15627196/Obat_dan_Penggolongannya. Diakses Februari.

Riwayat Ahmad No. 8048, 9756, 10194, Abu Dawud No. 3870, dan at-Tirmidzi No. 2045

Sholeh, Asrorun Ni'am. (2015). Jaminan Halal Pada Produk Obat: Kajian Fatwa MUI dan Penyerapannya dalam UU Jaminan Produk Halal. Jurnal Syariah. Edisi: Jurnal syariah 3 , November.

Zulham zulham, https://scholar.google.co.id/ Universitas Islam Negeri Sumatera Utara. 